\title{
Analiza wpływu szorstkości powierzchni styku jako parametru ksztaltującego nośność styku zespolonych elementów betonowych
}

\section{Dominika Franczak-Balmas}

\author{
Katedra Konstrukcji Budowlanych, Wydziat Budownictwa i Architektury, \\ Politechnika Lubelska, e-mail:d.franczak@pollub.pl
}

Streszczenie: W artykule przedstawiono wyniki oraz analizę badań nośności styku próbek złożonych z dwóch betonów, badanych na rozciąganie przez rozłupywanie. Analizie poddano wpływ szorstkości betonu pierwotnego jako parametru kształtującego nośność w styku betonowych elementów zespolonych.

Słowa kluczowe: szorstkość styku, betonowe konstrukcje zespolone, przyczepność, styk, nośność styku

\section{Wprowadzenie}

Naprężenia przyczepności stanowią istotne zagadnienie $\mathrm{w}$ analizie pracy statycznej elementów, w których występuje zespolenie pomiędzy betonami wyprodukowanymi w różnym czasie. Połączenia takie, poprzez kształtowanie styków zbrojonych bądź niezbrojonych, realizowane są w elementach zespolonych, złączach konstrukcji prefabrykowanych, występują również w strefach napraw i wzmocnień elementów betonowych lub jako przerwy technologiczne $[1,2]$. W połączeniach kontaktowych typu beton-beton w stykach przerw technologicznych, napraw czy wzmocnień szczególnie istotnym parametrem jest rysoodporność styku, o której decydują naprężenia przyczepności.

W podejściu do wyznaczania nośności styku zbrojonego na ścinanie zawartym w prenormie fib Model Code 2010 [3] występują zmiany w porównaniu z aktualną normą EC2-11 [4]. Zgodnie z EC2-1-1 nośność styku należy wyznaczyć jako sumę maksymalnych wartości poszczególnych składników, natomiast w MC2010 ilościowo rozróżniono udział poszczególnych składników tejże nośności w zależności od wartości poślizgu w styku. Istotną zmianą jest również uwzględnienie dodatkowego składnika nośności, jakim jest praca trzpieniowa zbrojenia zszywającego styk. Tak więc wyróżniono trzy główne składniki stanowiące nośność na ścinanie styku zbrojonego opisane jako mechanizmy:

A - zazębiania mechanicznego i połączenia adhezyjnego,

B - tarcia wskutek zewnętrznych sił ściskających prostopadłych do styku oraz sił spinających jako skutek występowania zbrojenia i/lub łączników,

$\mathrm{C}$ - trzpieniowego działania zbrojenia i/lub łączników przecinających styk.

Nośność graniczna styku na ścinanie opisana jest ogólnym wzorem:

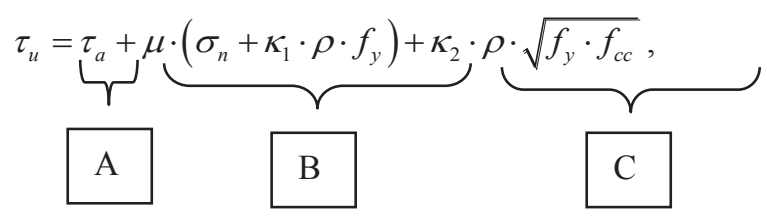


gdzie: $\tau_{a}$ - nośność na ścinanie jako suma połączenia adhezyjnego i zazębiania, $\mu$ - współczynnik tarcia $\mathrm{w}$ styku, $\sigma_{n}$ - najniższe naprężenie ściskające wynikające z działania siły normalnej do płaszczyzny styku, $\rho$ - stopień zbrojenia przecinającego styk, $\kappa_{1}-$ współczynnik interakcji siły rozciągającej wzbudzonej w prętach zbrojenia, $\kappa_{2}$ - współczynnik interakcji dla nośności zginania.

Zagadnienie nośności styku zbrojonego na ścinanie w ujęciu prenormy fib Model Code 2010 [3] oraz EC 2-1-1 [4] opisano szerzej w pracy [5]. W niniejszym artykule przedmiotem rozważań jest mechanizm połączenia adhezyjnego i zazębiania mechanicznego jako czynnika wpływającego na wartość naprężeń przyczepności styku pomiędzy betonami.

\section{Rola i udział adhezji w nośności styku ścinanego według prenormy Model Code 2010}

W stykach zbrojonych przekroczenie naprężeń przyczepności oraz przemieszczenie i/lub rozwarstwienie wzajemne elementów zespolonych jest warunkiem decydującym o pracy zbrojenia zszywającego i powstania w nim naprężeń [6], a sztywność zespolenia wpływa na pracę statyczną elementów zespolonych [7]. W prenormie MC2010 wyraźnie to zaznaczono poprzez wprowadzenie podziału styków na sztywne i niesztywne w zależności od charakterystyki „przyczepność-poślizg” oraz wprowadzenie współzależności mechanizmów decydujących o nośności styku na ścinanie.

W styku sztywnym główny składnik nośności na ścinanie stanowi silne połączenie adhezyjne (styk jest niezbrojony lub ilość zbrojenia przeszywającego styk jest niewielka tzn. $\rho<0,05 \%$ ). W takim przypadku zgodnie z prenormą udział pracy zbrojenia zszywającego należy pominąć i wyznaczyć nośność graniczną styku na ścinanie według wzoru:

$$
\tau_{R d i}=c_{a} f_{c t d}+\mu \sigma_{n} \leq 0,5 v f_{c d}
$$

gdzie: $c_{a}-$ współczynnik dla przyczepności adhezyjnej.

W przypadku styku niesztywnego, z uwagi na słabe połączenie adhezyjne, o nośności decydują tarcie oraz działanie trzpieniowe, a ilość zbrojenia zszywającego powinna spełniać warunek $\rho \geq 0,05 \%$. Nośność graniczną dla styku niesztywnego należy obliczyć według wzoru:

$$
\tau_{R d i}=c_{r} f_{c k}^{\frac{1}{3}}+\mu \sigma_{n}+\kappa_{1} \rho f_{y d}(\mu \cdot \sin \alpha+\cos \alpha)+\kappa_{2} \rho \sqrt{f_{y d} f_{c d}} \leq \beta_{c} v f_{c d}
$$

gdzie: $c_{r}$ - współczynnik wpływu zazębiania kruszywa w szorstkim styku, $\beta_{c}$ - współczynnik dla wytrzymałości ściskanego zastrzału.

Zgodnie z MC2010 parametrem decydującym o ilościowym współudziale poszczególnych składników w granicznej nośności styków ścinanych jest jego szorstkość. Wartości współczynników $c_{a}, c_{r}, \kappa_{1}, \kappa_{2}$ oraz $\mu$ zastosowanych we wzorach $(2,3)$ w zależności od szorstkości powierzchni styku zestawiono w Tab. 1.

Jako główne czynniki wpływające na przyczepność adhezyjną w prenormie MC2010 wyróżnione zostały szorstkość powierzchni styku oraz czystość styku. W licznych badaniach naukowych potwierdzono również wpływ innych czynników na nośność styku, które zostały wymienione w komentarzu do prenormy. Są to następujące parametry: klasa wytrzymałości łączonych betonów [8, 9, 10], właściwości betonu „starego” takie jak: jakość warstwy przystykowej [10,11], porowatość i wilgotność [12], właściwości betonu „,nowego" takie jak: jakość, skład [13, 14], skurcz, wiek [13, 8]. W komentarzu do prenormy nie wymieniono natomiast wpływu zastosowania warstw sczepnych, warunków pielęgnacji, w tym temperatury, a także efektu skali [15]. 
Tabela 1. Współczynniki dla różnych szorstkości powierzchni według [3]

\begin{tabular}{|c|c|c|c|c|c|c|c|}
\hline \multicolumn{2}{|l|}{ charakterystyka powierzchni styku } & \multirow[t]{2}{*}{$c_{a}$} & \multirow[t]{2}{*}{$\kappa c_{r}$} & \multirow[t]{2}{*}{$\kappa$} & \multirow[t]{2}{*}{$\kappa 2$} & \multicolumn{2}{|c|}{$\mu$} \\
\hline szorstkość & $R_{t}[\mathrm{~mm}]$ & & & & & $f_{\mathrm{ck}} \geq 20$ & $f_{\mathrm{ck}} \geq 35$ \\
\hline bardzo szorstka (w tym wręby) & $\geq 3,0 \mathrm{~mm}$ & 0,5 & 0,2 & 0,5 & 0,9 & 0,8 & 1,0 \\
\hline szorstka (silnie chropowata) & $\geq 1,5 \mathrm{~mm}$ & 0,4 & 0,1 & 0,5 & 0,9 & & \\
\hline gładka* & - & 0,2 & 0 & 0,5 & 1,1 & & \\
\hline bardzo gładka** & - & 0,025 & 0 & 0 & 1,5 & & \\
\hline
\end{tabular}

* powierzchnia betonu bez obróbki po wibrowaniu lub lekko chropowata po deskowaniu

** deskowanie stalowe, plastikowe, ze sklejki

Podkreślić należy, iż wyznaczenie granicznej nośności ze wzorów $(2,3)$ dla celów projektowych, wymaga uwzględnienia jedynie wpływu szorstkości powierzchni jako parametru pozwalającego na ilościowe określenie współudziału poszczególnych składników w tejże nośności. Wartość składnika adhezji oprócz szorstkości zależna jest od wytrzymałości betonu, przy czym nie wskazano, którą wytrzymałość - betonu starego czy nadbetonu, należy wziąć pod uwagę.

\section{Chropowatość powierzchni}

Stopień uszorstnienia powierzchni wpływa istotnie na adhezję mechaniczną, której istotą działania jest mechaniczne klinowanie elementów składowych przy wykorzystaniu nierówności i porów na powierzchni łączonych materiałów. Poprzez stosowanie obróbki mechanicznej powierzchni styku, a więc rozwinięcie nierówności powierzchni i zwiększenie pola powierzchni kontaktu, można kształtować naprężenia przyczepności. Należy jednak pamiętać, iż agresywność zastosowanej metody obróbki i związana z nią możliwość powstania mikropęknięć i uszkodzenia przypowierzchniowej warstwy betonu może wpływać na naprężenia przyczepności, choć jak wskazują badacze [10] wpływ ten jest niejednoznaczny. Na korzystny wpływ wzrostu stopnia uszorstnienia na przyczepność pull-off wskazują badacze $[10,11]$ w przypadku podkładów wykonanych z betonów wyższych klas natomiast odwrotny trend $\mathrm{z}$ uwagi na powstanie większych mikropęknięć na skutek zastosowania agresywnych metod obróbki podłoża obserwuje się w przypadku niższych klas betonu pierwotnego. Wpływ rodzaju obróbki na stopień zarysowania warstw powierzchniowych podkładu betonowego oraz metody jego oceny zostały omówione w [11]. W pracy tej badacze podkreślają, iż obok wpływu stopnia zarysowania podkładu na przyczepność należy wziąć pod uwagę również jego chropowatość. Spadek przyczepności przy podkładach o małym stopniu chropowatości następuje wraz ze wzrostem stopnia jego zarysowania. Natomiast w przypadku oceny podkładów o podobnym stopniu zarysowania, ale różniącym się stopniem chropowatości badacze [11] wskazują, iż znaczny wzrost chropowatości korzystnie wpływa na przyczepność.

W prenormie fib Model Code 2010 wymienione zostały dwa parametry służące do ilościowego określenia charakterystyki szorstkości powierzchni styku. Pierwszym z nich jest szorstkość średnia $R_{a}$ opisująca średnie odchylenie profilu powierzchni od linii średniej $(\bar{y})$ na odcinku o długości $l$ (Rys. 1):

$$
R_{a}=\frac{1}{l} \cdot \int_{0}^{l}|y(x)-\bar{y}| \cdot d x \approx \frac{1}{n} \sum_{i=1}^{n}\left|y_{i}-\bar{y}\right|
$$




$$
\bar{y}=\frac{1}{l} \cdot \int_{0}^{l} y(x) \cdot d x \approx \frac{1}{n} \sum_{i=1}^{n} y_{i}(x)
$$

gdzie: $l$-długość odcinka oceny, $y_{i}(x)$ - wysokość profilu w miejscu opisanym rzędną $x$.

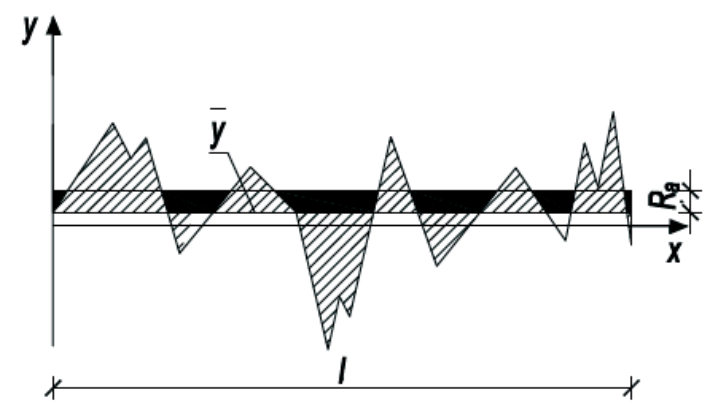

Rys. 1. Średnia szorstkość według [3]

Drugim parametrem jest ,średnia wysokość od szczytu do doliny” $R_{z}$ opisująca średnie maksymalne odchylenia szczytu do doliny w pewnej liczbie przedziałów oceny (Rys. 2):

$$
R_{z}=\frac{1}{n} \sum_{i=1}^{n} R_{z i}
$$

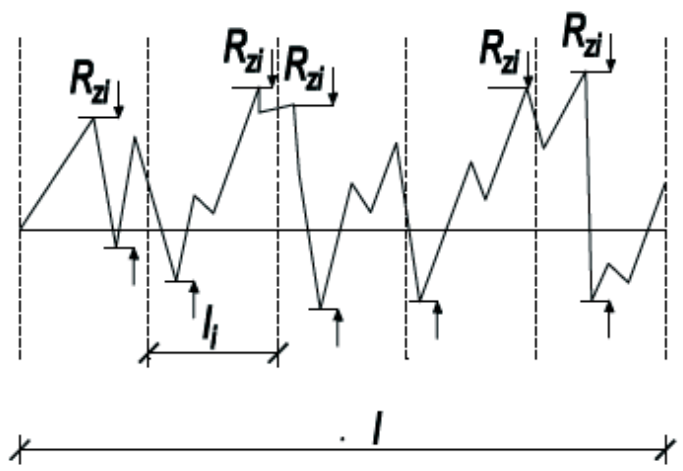

Rys. 2. Wysokości maksymalne od ,szczytu do doliny $R_{z i}$ w pięciu przedziałach $\left(l_{i}=1 / 5\right)$ według [3]

Pomimo zdefiniowania parametrów $R_{a}, R_{z}$ w MC2010 klasyfikację podziału szorstkości powierzchni na kategorie przedstawiono jedynie na podstawie parametru szorstkości $R_{t}$ (Tab. 2), będącego wynikiem badania szorstkości powierzchni metodą wyrównania piaskiem. Zastosowanie tej metody ograniczone jest jednak jedynie do badania powierzchni poziomych oraz charakteryzujących się stosunkowo dużą chropowatością. Natomiast nie uwzględniono przy kategoryzacji szorstkości powierzchni wartości dwóch pozostałych parametrów $R_{a}, R_{z}$, podano jedynie przybliżoną zależność pomiędzy dwoma parametrami opisaną wzorem:

$$
R_{t} \approx \frac{R_{z}}{2}
$$


Podana klasyfikacja na kategorie szorstkości jest klasyfikacją uproszczoną znajdującą zastosowanie w inżynierskiej praktyce projektowej, lecz, jak podkreślono w [3], ostateczną ocenę kategorii szorstkości powinna stanowić ocena inżynierska wspomagana metodami badawczymi w tym badaniami topografii powierzchni.

Tabela 2. Klasyfikacja szorstkości powierzchni [3]

\begin{tabular}{llc}
\hline Kategoria powierzchni & metoda obróbki powierzchni & $R_{t}[\mathrm{~mm}]$ \\
\hline bardzo szorstka & $\begin{array}{l}\text { np. obrabiana strumieniem wody pod wysokim ciśnie- } \\
\text { niem, nacinana }\end{array}$ & $\geq 3,0 \mathrm{~mm}$ \\
\hline szorstka & np. nieobrabiana, lekko chropowata & $\geq 1,5 \mathrm{~mm}$ \\
\hline gładka & np. piaskowana, czyszczona wodą pod strumieniem itp. & $<1,5 \mathrm{~mm}$ \\
\hline bardzo gładka & np. betonowa w stalowej formie & niemierzalne \\
\hline
\end{tabular}

Obok wspomnianej metody piaskowej badania szorstkości wymieniono w [3] metody badania $\mathrm{z}$ wykorzystaniem profilometru mechanicznego, triangulacji laserowej oraz fotogrametrii. Metody te zostały szerzej opisane w [10].

\section{Program i przebieg badań}

Celem badań było rozpoznanie, jaki wpływ na kształtowane adhezji w styku elementów zespolonych typu „,beton-beton” ma szorstkość powierzchni betonu pierwotnego - „starego”. Badania główne wykonano na zespolonych próbkach sześciennych o wymiarach 150x150x150 mm poddanych rozciąganiu przez rozłupywanie. Styk między betonami usytuowany był pionowo, w osi przykładanych sił. Schemat badań przedstawiono na Rys. 3.

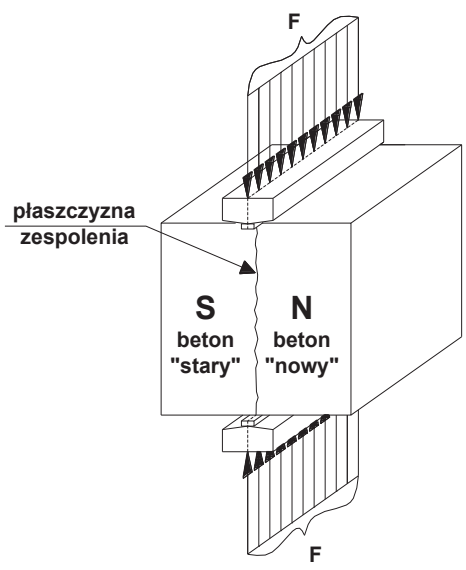

Rys. 3. Schemat badań próbek zespolonych

Badania podzielono na trzy serie próbek, w każdej zastosowano inny sposób ukształtowania powierzchni styku w celu uzyskania różnych tekstur jego uszorstnienia. Próbki zostały wykonane dwuetapowo. W pierwszym etapie w formach układano beton „stary”, pozostałą przestrzeń w seriach R oraz RG wypełniając styropianem, a w serii RP gładką sklejką laminowaną. Po okresie 14 dni dojrzewania betonu „starego” dobetonowywano „,nowy” beton. Nie czekano na osiągnięcie wieku 28 dni, ponieważ przy odpowiednich 
warunkach pielęgnacji betonu naprężenia przyczepności już w pierwszych kilkunastu dniach dojrzewania osiągają ok. 80-90 procent wartości 28-dniowej [16].

Powierzchnię styku betonu „starego” w seriach R oraz RP przed dobetonowaniem przygotowywano poprzez oczyszczenie z mleczka cementowego stalowymi szczotkami oraz nawilżenie wodą. Powierzchnię styku próbek RG uszorstniono mechanicznie przy zastosowaniu młotka udarowego o ciężarze $6,1 \mathrm{~kg} \mathrm{z}$ końcówką do groszkowania betonu, a następnie nawilżono wodą.

Skład mieszanki betonowej wykonanej z cementu CEM I 32,5 R przedstawiono w Tab. 3. Podczas dojrzewania próbki poddawane były pielęgnacji poprzez nawilżanie wodą. Badania realizowano po 14 dniach dojrzewania betonu „nowego”.

Tabela 3. Skład mieszanek betonowych

\begin{tabular}{ccccc}
\hline $\begin{array}{c}\text { cement } \\
{\left[\mathrm{kg} / \mathrm{m}^{3}\right]}\end{array}$ & $\begin{array}{c}\text { woda } \\
{\left[1 / \mathrm{m}^{3}\right]}\end{array}$ & $\begin{array}{c}\text { piasek } \\
{\left[\mathrm{kg} / \mathrm{m}^{3}\right]}\end{array}$ & $\begin{array}{c}\dot{\mathrm{z} w i r} \\
{\left[\mathrm{~kg} / \mathrm{m}^{3}\right]}\end{array}$ & w/c \\
\hline 465 & 177 & 455 & 1330 & 0,38 \\
\hline
\end{tabular}

\section{Wyniki badań}

Szczegółowe wyniki badań próbek zestawiono w Tab. 4. Podano tu parametry wytrzymałościowe użytych materiałów - średnie wytrzymałości na ściskanie i rozciąganie oraz średnie nośności styku próbek zespolonych na rozciąganie $\left(\sigma_{c r m, z}\right)$, utożsamiane z naprężeniem powodującym zarysowanie styku (Rys. 6). Nośność styku próbek zespolonych ustalono na podstawie badań próbek rozłupywanych korzystając z analogii do wzoru normowego [4]:

$$
f_{c t m}=0,9 \cdot f_{c t m, s p}
$$

Średnie wytrzymałości próbek monolitycznych wyznaczono z wyników badań trzech próbek, natomiast nośność styku na rozciąganie - pięciu próbek w serii $\mathrm{R}$ i siedmiu próbek W serii RG. Współczynniki zmienności wyników nośności styku na rozciąganie osiągały wartości $11,2 \%$ dla serii RG oraz 14,6\% dla serii R.

Tabela 4. Wyniki badań.

\begin{tabular}{|c|c|c|c|c|c|c|c|c|}
\hline \multirow{3}{*}{$\cdot \stackrel{\frac{\pi}{2}}{\mathbb{D}^{\circ}}$} & \multicolumn{4}{|c|}{ wytrzymałość betonów składowych } & \multirow{2}{*}{\multicolumn{3}{|c|}{$\begin{array}{l}\text { nośność styku } \\
\text { na rozciąganie }\end{array}$}} & \multirow{3}{*}{$\begin{array}{c}\begin{array}{c}\text { średnia } \\
\text { szorstkość }\end{array} \\
R_{a} \\
{[\mathrm{~mm}]}\end{array}$} \\
\hline & \multicolumn{2}{|c|}{ beton stary } & \multicolumn{2}{|c|}{ beton nowy } & & & & \\
\hline & $\begin{array}{c}f_{c m} \\
{[\mathrm{MPa}]}\end{array}$ & $\begin{array}{c}f_{c t m} \\
{[\mathrm{MPa}]}\end{array}$ & $\begin{array}{c}f_{c m} \\
{[\mathrm{MPa}]}\end{array}$ & $\begin{array}{c}f_{c t m} \\
{[\mathrm{MPa}]}\end{array}$ & $\begin{array}{c}\sigma_{c r m, z} \\
{[\mathrm{MPa}]}\end{array}$ & $\begin{array}{c}\sigma_{f c r m, z} \\
{[\mathrm{MPa}]}\end{array}$ & $\begin{array}{l}V_{f c r m, z} \\
{[\%]}\end{array}$ & \\
\hline RG & 49,35 & 3,27 & 46,98 & 3,02 & 1,72 & 0,19 & $11,19 \%$ & 0,43 \\
\hline $\mathrm{R}$ & 54,25 & 3,00 & 47,36 & 2,52 & 1,08 & 0,16 & $14,60 \%$ & 0,24 \\
\hline $\mathrm{RP}$ & - & - & - & - & - & - & - & 0,14 \\
\hline
\end{tabular}

Wyniki badań wytrzymałościowych 7 próbek serii RP, w której powierzchnię styku uzyskano z laminowanej sklejki pominięto w dalszej analizie z uwagi na fakt, iż nie uzyskano wystarczającego połączenia adhezyjnego a wartość współczynnika zmienności wyników nośności styku przekroczyła 50\%.

Reprezentatywne obrazy zniszczenia próbek zespolonych wszystkich serii przedstawiono na Rys. 4. Zniszczenie wszystkich próbek zespolonych serii R nastąpiło poprzez rozwarstwienie w płaszczyźnie styku w zaczynie cementowym. Po zniszczeniu próbek serii 
R na powierzchni styku betonu „starego” widoczny był zaczyn, który wniknął w nierówności styku (Rys. 4b). W przypadku serii RG zaobserwowano zniszczenie poprzez rozwarstwienie w płaszczyźnie styku w warstwie przypowierzchniowej betonu „nowego” Z widocznym odsłonięciem i/lub zniszczeniem kruszywa. W przypadku próbek serii RP zniszczenie nastąpiło poprzez pęknięcie w płaszczyźnie styku przy czym nie zaobserwowano wyraźnych śladów zaczynu cementowego.

a)

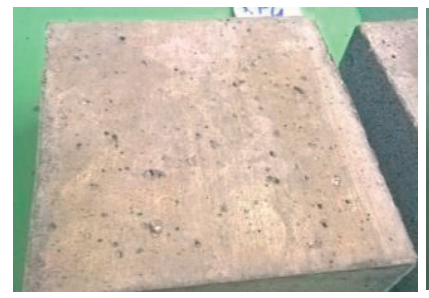

Rys. 4. Obrazy zniszczenia próbek zespolonych serii: a) RP, b) R, c) RG b)

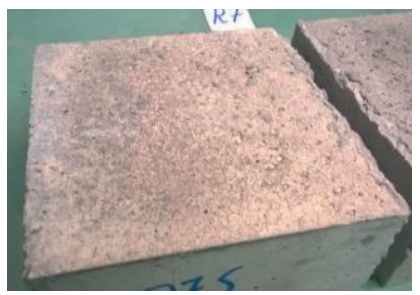

c)

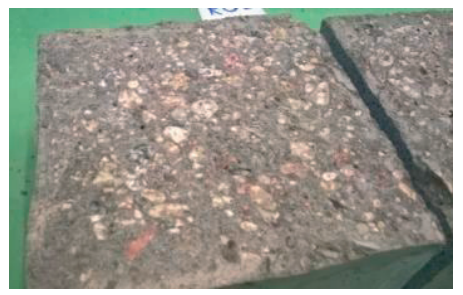

a)

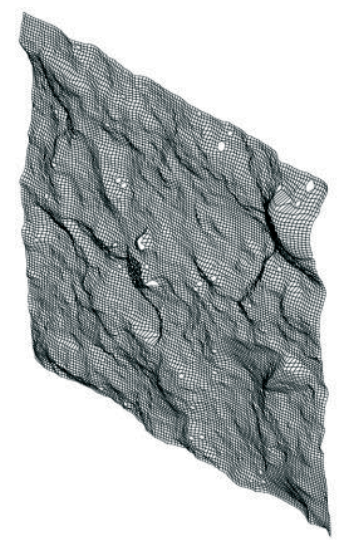

b)

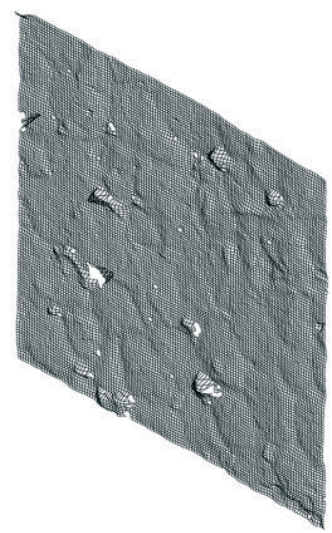

c)

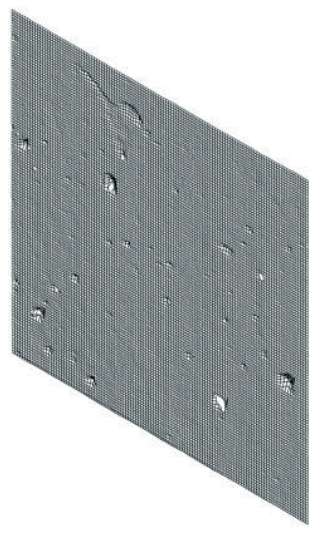

Rys. 5. Obrazy fragmentów skanów powierzchni styku betonu „starego” otrzymane w wyniku skanowania laserem 3D w seriach próbek: a) RG (powierzchnia obrabiana młotem udarowym o wadze $6,1 \mathrm{~kg}$ ), b) R (powierzchnia uzyskana ze styropianu) i c) RP (powierzchnia uzyskana z gładkiej sklejki laminowanej)

Chropowatość powierzchni betonu „starego” przed dobetonowaniem betonu „nowego" została oceniona na podstawie topografii tej powierzchni przy zastosowaniu skanera laserowego 3D Picza Laser Scanner LPX-600. Pomiary wykonano z rozdzielczością $0,2 \mathrm{~mm}, \mathrm{z}$ uzyskanych współrzędnych punktów obliczono średnią szorstkość styku $R_{a}$ korzystając ze wzorów $(4,5)$. Obliczone wartości średniej szorstkości $R_{a}$ zestawiono w Tab. 4. Obrazy skanów powierzchni wybranych próbek pokazano na Rys. 5.

Na Rys. 7 przedstawiono graficznie wyniki obliczeń średniej szorstkości styku próbek, wyniosła ona odpowiednio dla próbek serii: $\mathrm{RP}-0,14 \mathrm{~mm}, \mathrm{R}-0,24 \mathrm{~mm}$ i RG $0,43 \mathrm{~mm}$. 


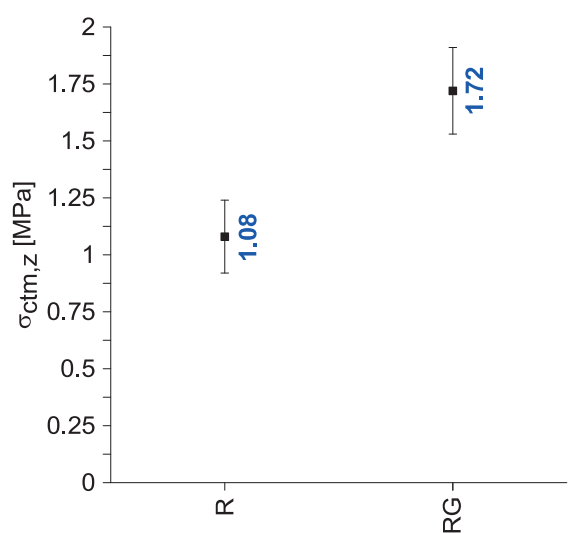

Rys. 6. Nośność styku na rozciąganie próbek zespolonych serii R i RG

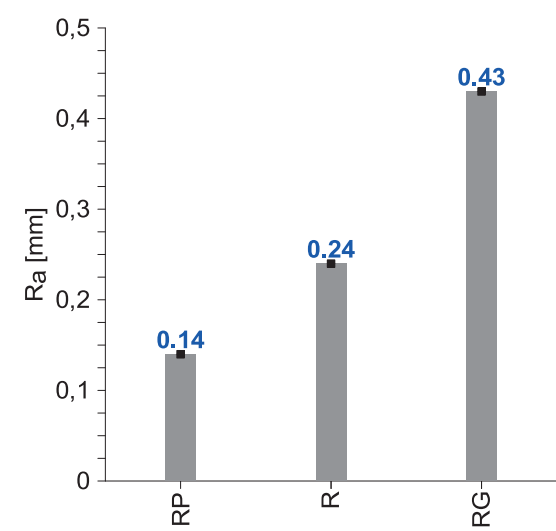

Rys. 7. Średnia szorstkość powierzchni styku betonu "starego"

\section{Analiza wyników}

Porównując wyniki przedstawione na Rys. 6 i Rys. 7 można stwierdzić, że wyższą nośność styku $\left(\sigma_{\mathrm{crm}, \mathrm{z}}\right)$ zaobserwowano w przypadku próbek o większej chropowatości powierzchni styku, przyrost współczynnika średniej chropowatości $R_{\mathrm{a}}$ o $80 \%$ (od wartości $0,24 \mathrm{~mm}$ dla serii $\mathrm{R}$ do $0,43 \mathrm{~mm}$ dla serii $\mathrm{RG}$ ) skutkował przyrostem nośności styku o blisko 60\% (od wartości 1,08 MPa dla serii R do 1,72 MPa dla serii RG).

W przypadku próbek serii RP (powierzchnia styku uzyskana z gładkiej laminowanej sklejki) powierzchnię styku można zakwalifikować do kategorii bardzo gładkiej. Dla tej serii nie uzyskano wystarczającego połączenia adhezyjnego na co wskazuje obraz zniszczenia (Rys. 4a) bez widocznego zaczynu w styku oraz duży współczynnik zmienności wyników nośności styku.

Powierzchnię styku próbek serii R można zakwalifikować do kategorii gładkiej, po zniszczeniu tej serii próbek na powierzchni styku betonu „starego” wyraźnie widoczny był zaczyn betonu „nowego”, który wniknął w nierówności styku (Rys. 4b), wystąpiło zniszczenie adhezyjne. Powierzchnię betonu „starego" w serii próbek RG, na podstawie metody obróbki przeprowadzonej przy użyciu młota udarowego można zakwalifikować co najmniej do kategorii szorstkiej. Obraz zniszczenia (Rys. 4c) ukazuje głównie zniszczenie przystykowej warstwy nadbetonu z towarzyszącym zniszczeniem (rozłupaniem) kruszywa. Obraz ten świadczy o bardziej efektywnym wniknięciu zaczynu nadbetonu w pory i nierówności betonu „starego” w przypadku zastosowania obróbki mechanicznej niż w przypadku próbek serii R oraz działaniu adhezji mechanicznej (zazębianie się cząstek).

Do analizy wyników badań zastosowano współczynnik efektywności zespolenia $\alpha_{c r}$ (Rys. 8) zdefiniowany jako:

$$
\alpha_{c r}=\frac{\sigma_{c r m, z}}{f_{c t m}}
$$

gdzie: $\sigma_{c r m, z}$ - średnie naprężenia rysujące styk próbki zespolonej, $f_{c t m}$ - średnia wytrzymałość na rozciąganie słabszego z betonów.

Wartości tego współczynnika zobrazowano na Rys. 8.

Ponieważ nośność styku, zależy od wytrzymałości obydwu betonów [8], wyznaczono również średni współczynnik efektywności zespolenia $\beta_{c r}$ (Rys. 9) zdefiniowany jako: 


$$
\beta_{c r}=\frac{\sigma_{c r m, z}}{\frac{f_{c t m, S}+f_{c t m, N}}{2}}
$$

gdzie: $\sigma_{c r m, z}$ - średnie naprężenia rysujące styk próbki zespolonej, $f_{c t m, S}$ - średnia wytrzymałość na rozciąganie betonu „starego”, $f_{c t m, N}$ - średnia wytrzymałość na rozciąganie betonu „nowego".

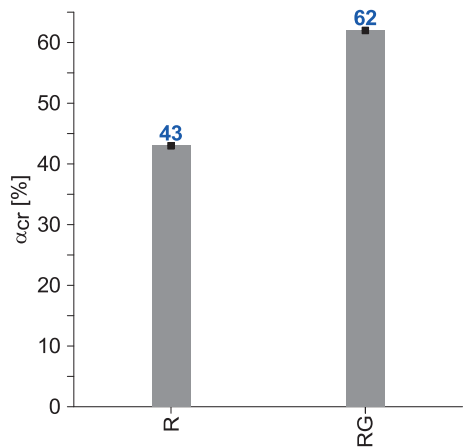

Rys. 8. Współczynnik efektywności zespolenia styku próbek

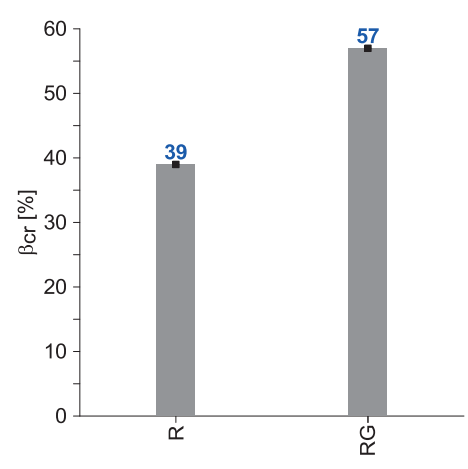

Rys. 9. Średni współczynnik efektywności zespolenia

Analizując Rys. 8 oraz Rys. 9 zaobserwowano wyraźny wzrost wartości współczynników efektywności zespolenia ze wzrostem chropowatości styku. Współczynnik $\alpha_{c r}$ wzrósł od $43 \%$ a $\beta_{c r}$ od $39 \%$ w przypadku serii R (dla której $\left.R_{a}=0,24 \mathrm{~mm}\right)$ do $62 \%\left(\alpha_{c r}\right)$ oraz do $57 \%\left(\beta_{c r}\right)$ w przypadku serii RG (dla której $R_{\mathrm{a}}=0,43 \mathrm{~mm}$ ). Zatem zwiększenie wartości wskaźnika średniej szorstkości o 80\% skutkowało przyrostem wartości współczynnika efektywności zespolenia $\alpha_{c r}$ oraz średniego współczynnika efektywności zespolenia $\beta_{c r}$ o $45 \%$.

\section{Wnioski}

Na podstawie przeprowadzonych badań, w odniesieniu do nośności styku dwóch betonów można stwierdzić, co następuje:

- Sposób przygotowania powierzchni styku istotnie wpływa na kształtowanie jego nośności. Adhezja mechaniczna jest kluczowym składnikiem nośności styku ponieważ wraz ze wzrostem chropowatości powierzchni (rozwinięcie pola powierzchni kontaktu) rośnie jego nośność (wzrost o 60\%), współczynnik efektywności zespolenia oraz średni współczynnik efektywności zespolenia (wzrost o 45\%)

- W przypadku bardzo gładkich powierzchni praktycznie nie uzyskano przyczepność adhezyjnej w styku między betonami. Aby zaczyn cementowy mógł wniknąć w pory i nierówności podkładu betonowego powierzchnia styku musi posiadać widoczne nierówności i być co najmniej gładka.

\section{Literatura}

1. Halicka A., Franczak D., Fronczyk J., Analiza przyczyn zarysowań cylindrycznego zbiornika żelbetowego ujawnionych podczas próby szczelności. Przegląd Budowlany 4 (2012) 35-41. 
2. Kamiński M., Maj M., Kmiecik P., Wpływ technologii ksztaltowania przerw roboczych w aspekcie zachowania właściwej nośności ścian zbiorników i kominów żelbetowych. Przegląd Budowlany 4 (2012) 125-129.

3. Prenorma konstrukcji betonowych - fib Model Code 2010. Wydawnictwo Polski Cement, Kraków 2014.

4. PN-EN 1992-1-1:2008 Eurokod 2: Projektowanie konstrukcji z betonu. Część 1-1: Reguły ogólne I reguły dla budynków.

5. Halicka A., Jabłoński Ł., Styk między betonami układanymi $w$ różnym czasie - parametry $i$ nośność wedtug fib Model Code 2010. Inżynieria i Budownictwo 7 (2015) 346-350.

6. Halicka A., Studium naprężeń i odkształceń w plaszczyźnie styku i strefie przypodporowej elementów zespolonych z udziatem betonów skurczowych i ekspansywnych. Wydawnictwa Uczelniane, Lublin 2007.

7. Gromysz K., Badania żelbetowych płyt warstwowych obciażonych doraźnie, cyklicznie i kinematycznie. Wydawnictwo Politechniki Śląskiej, Gliwice 2013.

8. Franczak-Balmas D., Analiza wpływu wytrzymałości betonów składowych jako czynnika ksztattujacego nośność niezbrojonego styku zespolonych elementów betonowych. Budownictwo i Architektura 15(4) (2016) 53-61.

9. Beushausen H., Alexander M.G., Bond strength development between concretes of different ages. Magazine of Concrete Research 60(1) (2008) 65 $\div 74$.

10. Garbacz A., Piotrowski T., Courard L., Inżynieria powierzchni betonu. Część 1. Struktura geometryczna powierzchni. Materiały Budowlane 9 (2006) 3-7.

11. Courard L., Garbacz A., Niewęgłowska-Mazurkiewicz A., Piotrowski T., Inżynieria powierzchni betonu. Częśś 2. Wpływ obróbki na powstawanie rys. Materiały Budowlane 12 (2006) 8-11.

12. Beushausen H., Hohlig B., Talotti M., The influence of substrate moisture preparation on bond strength of concrete overlays and the microstructure of the OTZ. Cement and Concrete Research 92 (2017) 84-91.

13. Franczak D., Halicka A., Wpływ wieku betonu na nośność styku w elementach zespolonych typu „, beton-beton”. Przegląd Budowlany 1 (2012) 46-51.

14. Hak-Chul Shin, Zhifu Wan: Interfacial properties between New and Old Concretes. $2^{\text {nd }}$ International Conference on Sustainable Construction Materials and Technologies, Ancona, Italy 2010.

15. Halicka A., Franczak-Balmas D., The size effect in monolithic and composite concrete members. Part 2, Cement Lime Concrete 1 (2014) 262-266.

16. Halicka A., Franczak D., Rozwój przyczepności między dwoma betonami w czasie twardnienia betonu. Wydawnictwa Uczelniane, Lublin 2009.

\title{
An analysis of the impact surface roughness of concrete substrate as a factor influencing the bond strength in composite concrete elements
}

\author{
Dominika Franczak-Balmas \\ Lublin University of Technology, Faculty of Civil Engineering and Architecture, \\ Nadbystrzycka 40,20-618Lublin,e-mail:d.franczak@pollub.pl
}

\begin{abstract}
The article presents the results and analysis of the research of the bond strength between two concrete parts in composite member investigated by tensile splitting test. The study was conducted on three groups of specimens differing in substrate roughness. The impact of roughness of substrate on bond strength in the concrete composite elements is discussed.
\end{abstract}

Keywords: substrate roughness, composite members, bond, bond strength, adhesion. 